\title{
EFEKTIVITAS FREKUENSI LATIHAN BUERGER'S ALLEN TERHADAP ANKLE BRACHIAL INDEX PASIEN DIABETES MELITUS TIPE 2
}

\author{
Paridah \\ Jurusan Keperawatan Fakultas Ilmu Kesehatan Universitas Borneo Tarakan \\ Email: paridahida78@gmail.com
}

\begin{abstract}
Abstrak
Buerger's Allene exercises (BAE) adalah sistem latihan untuk insufisiensi arteri tungkai bawah dengan menggunakan perubahan gravitasi pada posisi yang diterapkan dan muscle pump yang terdiri dari dorsofleksi dan plantarfleksi melalui gerakan aktif dari pergelangan kaki untuk kelancaran otot pembuluh darah. Muscle pump dengan dorsofleksi dan plantarfleksi dapat merangsang endotel untuk mengeluarkan atau melepaskan nitrit oksida sehingga akan memberikan sinyal ke otot polos vaskular untuk relaksasi.Tujuan literature review ini untuk menilai efektivitas frekuensi Latihan Buerger's Allene terhadap nilai Ankle Brachial Indeks penderita Diabetes Melitus tipe 2. Strategi pencarian dalam Literature review ini didasarkan pada pencarian literature terhadap berbagai penelitian yang membahas tentang latihan Buerger Allens baik terpublikasi maupun tidak/belum terpublikasi, berbahasa Inggris atau Indonesia. Pencarian artikel dalam jurnal berasal dari beberapa database yang diterbitkan pada 10 tahun antara januari 2010 hingga januari 2020 yaitu Google scholar, PubMed, Proquest dengan menggunakan metode pencarian Problem, Intervention, Control, Outcome (PICO) dan jumlah artikel yang dianalisis sebanyak 9 artikel yang memenuhi kriteria inklusi RCT, review, tidak duplikasi, full text dengan kata kunci “Buerger Allens and Ankle Brachial Index”. Hasil: Frekuensi latihan BAE 2 kali sehari dan frekuensi BAE lebih dari 2 kali latihan tidak ada perbedaan. Keduanya dapat meningkatkan nilai ABI secara signifikan.
\end{abstract}

Kata Kunci : latihan Buerger's Allen, Ankle Brachial Index, DM tipe 2

\begin{abstract}
The Effectiveness of Buerger's Allen Exercise Frequency on Ankle Brachial Index Patients with Type 2 Diabetes Mellitus. Buerger's Allene exercises (BAE) is an exercise system for arterial insufficiency of the lower limbs using a change in gravity in the applied position and a muscle pump consisting of dorsiflexion and plantarflexion through active movement of the ankle to smooth muscle blood vessels. Muscle pump with dorsiflexion and plantarflexion can stimulate the endothelium to secrete or release nitric oxide so that it will provide a signal to vascular smooth muscle for relaxation. The purpose of this literature review is to assess the effectiveness of the frequency of Buerger's Allene exercise on the value of the Brachial Ankle Index in patients with Type 2 Diabetes Mellitus. Search strategy in this Literature review is based on a literature search of various studies discussing the Buerger Allens exercises, whether published or unpublished/unpublished, in English or Indonesian. The search for articles in journals comes from several databases published in 10 years between January 2010 to January 2020, namely Google scholar, PubMed, Proquest using the Problem, Intervention, Control, Outcome (PICO) search method and the number of articles analyzed is 9 articles that meet the criteria. RCT inclusion criteria, review, no duplication, full text with the keywords "Buerger Allens and Ankle Brachial Index". Results: The frequency of BAE exercise 2 times a day and the frequency of BAE more than 2 times there was no difference. Both can increase the ABI value significantly.
\end{abstract}

Keywords: Allen in Buerger's exercise, Ankle Brachial Index, DM type 2 


\section{Pendahuluan}

Buerger's Allene exercises (BAE) adalah sistem latihan untuk insufisiensi arteri tungkai bawah dengan menggunakan perubahan gravitasi pada posisi yang diterapkan dan muscle pump yang terdiri dari dorsofleksi dan plantarfleksi melalui gerakan aktif dari pergelangan kaki untuk kelancaran otot pembuluh darah. Muscle pump dengan dorsofleksi dan plantarfleksi dapat merangsang endotel untuk mengeluarkan atau melepaskan nitrit oksida sehingga akan memberikan sinyal ke otot polos vaskular untuk relaksasi. Pada saat sel otot-otot polos relaksasi maka pembuluh darah akan vasodilatasi sehingga aliran darah ke perifer kaki menjadi lancar (Purnawarman \& Nurkhalis, 2014). Sedangkan perubahan postural (gravitasi pada posisi yang diterapkan) pada BAE akan membantu mengosongkan dan mengisi kolom darah secara bergantian sehingga dapat meningkatkan transportasi darah melalui pembuluh darah (Sherwood, 2013). BAE merupakan bentuk latihan yang didasarkan pada gaya gravitasi untuk m1qeningkatkan transportasi darah vaskuler/vaskularisasi (C. F. Chang et al., 2015). Review yang dilakukan oleh C. Chang et al., (2015) menyimpulkan bahwa BAE dapat dijadikan sebagai prosedur alternatif untuk meningkatkan sirkulasi perifer. ABI adalah suatu tes yang digunakan secara langsung untuk mengkaji sirkulasi arteri ekstremitas bawah dan menentukan jumlah kompresi yang dapat dipasang secara aman pada pasien dengan ulserasi vena dan gangguan campuran arterial-vena (Maryunani, 2013). Evaluasi sirkulasi ini menggunakan doppler untuk menentukan ABI (Carville, 2007).

Review yang dilakukan oleh C. Chang et al., (2015), menyimpulkan bahwa BAE dapat dijadikan sebagai prosedur alternatif untuk meningkatkan sirkulasi perifer, namun berdasarkan hasil penelitian yang telah dilakukan, ditemukan ketidak seragaman dalam frekuensi pelaksanaan latihan BAE dalam sehari, oleh karena itu, literature review ini bertujuan untuk menilai efektivitas frekuensi Latihan Buerger's Allene terhadap nilai Ankle Brachial Indeks penderita Diabetes Melitus tipe 2.

\section{Metode}

Strategi pencarian dalam Literature review ini didasarkan pada pencarian literature terhadap berbagai 
penelitian yang membahas tentang latihan Buerger Allens baik terpublikasi maupun tidak/belum terpublikasi, berbahasa Inggris atau Indonesia. Pencarian artikel dalam jurnal berasal dari beberapa database yang diterbitkan pada 10 tahun antara januari 2010 hingga januari 2020 yaitu Google scholar, PubMed, Proquest dengan menggunakan metode pencarian Problem, Intervention, Control, Outcome (PICO) dan jumlah artikel yang dianalisis sebanyak 9 artikel yang memenuhi kriteria inklusi RCT, review, tidak duplikasi, full text dengan kata kunci "Buerger Allens AND Ankle Brachial Index”.

\section{Hasil}

Literature review ini memaparkan beberapa artikel yang mengulas tentang efek latihan BAE terhadap ABI.

\section{A. Frekuensi latihan BAE 2 kali sehari}

Penelitian yang dilakukan oleh Priya (2016) mengatakan bahwa pemberian latihan BAE selama 2 kali/hari dengan interval 6 jam dalam kurun waktu 5 hari menunjukkan hasil peningkatan nilai ABI. Pada penelitian yang dilakukan dengan membanding BAE (kelompok intervensi) dengan manajemen terapi biasa (kelompok control) terhadap nilai ABI didapatkan hasil bahwa terdapat perbedaan yang signifikan $(\mathrm{p}<0,05)$ dengan nilai mean retest antara kelompok intervensi dengan kelompok control dengan nilai mean pretest nilai 0,922 dengan SD 0,0562 dan mean post-test nilai 0,980 dengan SD 0,0407 yang memproyeksikan bahwa nilai t 9,108 (John \& Rathiga, 2015).

Hal yang sama juga terjadi pada penelitian yang dilakukan 2 kali sehari selama 3 inggu pada pasien yang mengalami luka kaki diabetic (LKD), pada penelitian tersebut ditemukan perbedaan yang signifikan antara pre dan post test BAE terhadap rata-rata nilai $A B I$ yaitu sebelum test 0.84 dan sesudah tes $0.95(p=0.001)$ (Jannaim et al., 2018).

\section{B. Frekuensi latihan BAE lebih dari 2 kali sehari}

Pada penelitian yang menilai $\mathrm{ABI}$ dengan frekuensi latihan BAE selama 5 kali/hari dalam kurun waktu 5 hari menunjukkan hasil terjadi peningkatan perfusi ekstremitas bawah (Abishal, 2016), demikian pula penelitian yang dilakukan oleh Jinna Radhika, Geetha Poomalai (2020) menyatakan terdapat Perbedaan signifikan pada sindrom neuropati perifer setelah penerapan BAE 5 kali dalam sehari pada gangguan perfusi ekstremitas perifer kanan $\left(\mathrm{t}_{48}=6,81, p<0,001\right)$ 
dan kiri ( $\left.\mathrm{t}_{48}=5,21, p<0,001\right)$. Pada penelitian lain yang dilakukan selama 12 bulan dengan frekuensi 3 kali per hari durasi waktu setiap sesi 30 menit juga menunjukkan peningkatan signifikan nilai ABI sebelum dan sesudah test pada kaki kanan $(\mathrm{Z}=$ $-3.62, \mathrm{p}<.001)$, kaki kiri $(\mathrm{Z}=-4.22$, $\mathrm{p}<$.001) (C. F. Chang et al., 2015).

\section{Pembahasan}

Berdasarkan hasil telaah beberapa artikel yang dilakukan diperoleh data yang menampilkan bahwa frekuensi latihan BAE 2 kali dan frekuensi latihan BAE lebih dari 2 kali menunjukkan hasil yang tidak berbeda, dimana keduanya sama-sama memberikan pengaruh terhadap peningkatan nilai ABI yang secara statistik signifikan.

Hasil penelitian yang diperoleh dari BAE yang dikombinasikan dengan program promosi Kesehatan pertama adalah secara signifikan mengurangi vaskulopati perifer, neuropati, dan mengurangi ketidaknyamanan kaki pada pasien. Kedua, BAE merupakan program aktivitas fisik berbiaya rendah dan berisiko rendah. BAE yang dikombinasikan dengan program peningkatan kesehatan secara signifikan mengurangi indikator fisiologis vaskulopati perifer diabetik, neuropati perifer diabetes, dan ketidaknyamanan kaki (C. F. Chang et al., 2015).

Studi kepustakaan dan penelitian yang pernah dilakukan oleh Purnawarman \& Nurkhalis (2014) menyatakan bahwa keberadaan enzimatik yang bersifat vasodilator pada pembuluh darah sangat penting guna mencegah terjadinya disfungsi endotel, dan hal ini dapat dihindari melalui latihan fisik yang secara molekuler dapat meningkatkan ekspresi protein eNOS dan bioavailabilitas produknya, Nitrit Oksida (NO), yang merupakan enzim vasodilator pada endotel, Efek ini didapat karena perbaikan disfungsi endotel akibat peningkatan bioavailabilitas NO, penurunan degradasi NO, meningkatkan waktu paruh NO. BAE yang dilakukan pada pasien LKD untuk meningkatkan sirkulasi kolateral pada pasien dengan gangguan peredaran perifer menyatakan status hemodinamik kaki pasien yang mengalami iskemik dapat ditingkatkan secara efektif melalui perubahan posisi kaki secara berkala, disamping itu BAE dapat membantu pemenuhan glukosa/nutrisi dan oksigen dalam pembuluh darah arteri dan vena, sehingga sirkulasi darah menjadi adekuat yang membuat penyembuhan luka kaki diabetic lebih baik selain itu BAE juga dapat meningkatkan produksi insulin sehingga gula darah menurun, BAE juga dapat memperkuat dan memaksimalkan kerja otototot kecil (Tota et al., 2013). Merujuk pada ulasan tersebut maka dapat dikatakan bahwa intervensi BAE dapat diberikan pada penderita 
DM tanpa luka maupun yang disertai LKD, BAE juga memberikan keuntungan selain meningkatkan sirkulasi perifer juga berfungsi untuk meningkatkan kerja dan kekuatan otot pada daerah ekstremitas.

\section{Kesimpulan}

Hasil telaah literature review yang dilakukan bahwa frekuensi latihan BAE tidak berpengaruh terhadap nilai $\mathrm{ABI}$, dengan demikian dapat diasumsikan bahwa BAE dapat dilakukan kapan saja tanpa ada batasan jumlah frekuensi latihan. BAE dapat dijadikan sebagai salah satu intervensi yang dapat diterapkan dan cukup efektif meningkatkan sirkulasi perifer pada pasien DM yang cukup sensitif, efektif, spesifik, dan mudah dilakukan karena hanya cukup dengan membaca instruksi singkat dan tidak memerlukan biaya maupun alat dalam melakukannya serta tidak menimbulkan bahaya baik bagi pasien maupun pemeriksa, sehingga siapapun dapat melakukannya baik itu orang awam, saudara, dan teman. BAE juga dapat dilakukan di rumah maupun di pelayanan kesehatan/klinik.

\section{Referensi}

Abishal. (2016). A Study To Evaluate The Effectiveness Of Buerger-Allen Exercise In Improving Circulation Among Peripheral Diabetes Mellitus Patient In Hospital At Selected Kanyakumari District. Dissertation (Vol. 9, Issue 2). http://repository- tnmgrmu.ac.in/331/1/3001311abishala.p df

Carville, K. (2007). Wound Care Manual (5th ed.). The Silver Chain Nursing Association.

Chang, C., Chang, C., \& Chen, M. (2015). Effect of Buerger' $\mathrm{s}$ Exercises on Improving Peripheral Circulation: A Systematic Review. Scientific Research Publishing, February, 120-128. https://doi.org/http://dx.doi.org/10.4236/ ojn.2015.52014

Chang, C. F., Chang, C. C., Hwang, S. L., \& Chen, M. Y. (2015). Effects of Buerger Exercise Combined Health-Promoting Program on Peripheral Neuro Vasculopathy Among Community Residents at High Risk for Diabetic Foot Ulceration. Worldviews on EvidenceBased Nursing, 12(3), 145-153. https://doi.org/10.1111/wvn.12091

Jinna Radhika, Geetha Poomalai, R. R. (2020). Effectiveness of Buerger-Allen Exercise on Lower Extremity Perfusion and Peripheral Neuropathy Symptoms among Patients with Diabetes Mellitus. Iranian Journal of Nursing and Midwifery Research, 25(4), 291-295.

John, J., \& Rathiga, A. (2015). Effectiveness of Buerger Allen Exercise to Improve the Lower Extremity Perfusion among Patients with Type 2 Diabetes Mellitus. International Journal of Current Research and Academic Review, 3(4), 252-263.

https://pdfs.semanticscholar.org/2076/c7 94d4ef579387de9ec824c931267f50e75c. pdf

Maryunani, A. (2013). Modern Wound Care. In Media.

Priya, N. (2016). Effectiveness Of Buerger Allen Exercise On Levels Of Lower Extremity Perfusion Among Patients With Selected Non Communicable Diseases Ncds Admitted At Sri Narayani Hospital Branch-I Medical Surgical Nursing Among Patients With Selected Non. file:///D:/PENELITIAN/kumpulan 
Artikel ABI dan BAE/priya 2016.pdf

Purnawarman, A., \& Nurkhalis. (2014).

Pengaruh Latihan Fisik terhadap Fungsi

Endotel. Jurnal Kedokteran Syiah Kuala,

14(2), 109-118. http://www.jurnal.unsyiah.ac.id/JKS/arti cle/viewFile/2740/2588

Sherwood, L. (2013). Fisiologi Manusia Dari
Sel ke Sistem (O. H. Ong, A. A. Mahode, \& D. Ramadhani (eds.); 8th ed.). EGC.

Tota, K., Uemura, T., \& Murata, T. (2013). The effect of different positions on lower limbs skin perfusion pressure. Indian Journal of Plastic Surgery, 46(3), 508512. 